\title{
PREPARATION AND EVALUATION OF SOME BAKERY PRODUCTS VERY LOW IN PROTEIN FOR PHENYLKETONURIA PATIENTS
}

(Received: 27. 12 .2020)

\author{
By \\ M. A. Kamel, G.A. Zahran and Haiat M.N. Afify \\ Department of Bread and Pastry Research, Food Technology Research Institute, Agricultural \\ Research Centre, Giza, Egypt
}

\begin{abstract}
Potato flours and cornstarchare used to produce biscuits and flat bread for phenylketonuria(PKU) patients. The effect of thickening agents xanthan gum, Guar gum, carrageenan gum and mixturesofguar gum and carrageenan gum onphysical properties, hardness andsensory properties of biscuit and flat bread, were studied. The obtained results showed that the protein content of raw materials ranged between 0.10 to $6.12 \%$, while total carbohydrates ranged from 88.28to $99.48 \%$. The highest physical properties values (volume, thickness, diameter, spread ratio and specific volume), were in biscuit with xanthan gum. The hardness of biscuits decreased by adding gums. The thickening agents increased the sensory properties values of biscuits (taste and texture), whileit didnotaffect both color and odor of all biscuit samples compared with the control. The biscuit samples with xanthan gum and mixture of gums had the high acceptance. The highest moisture content was in xanthan gum of flat bread samples. The thickening agents caused increase in all samples of flat bread hardness compared with the control. The organoleptic results of flat bread showed that xanthan gum,guar gum, carrageenan gum and mixture of gums were more suitable to produce flat bread compared with the control samples. Potato flour and cornstarch, with thickening agents, can produce biscuits and flat bread low in protein for phenylketonuriapatients.
\end{abstract}

Keywords: low protein, phenylketonuria patients, thickening agent, flat bread, biscuits.

\section{INTRODUCTION}

Phenylketonuria(PKU) is an autosomal recessive disorder caused by a mutation in the Phenylalanine hydroxylase (PAH) Gene. This disorder results in accumulation of phenylalanine, which is an important amino acid metabolized in the liver by the Phenylalanine hydroxylase system. This enzyme hydroxylates thephenylalanine to tyrosine, which requires Tetrahydrobiopterin (BH4) as a cofactor. Defects in either PAH or the production, or recycling of $\mathrm{BH} 4$ may result in hyper phenilalaninemia which can cause intellectual disability if untreated individuals (Blau et al., 2010). The clinical severance of the phenol type of this disorder is directly correlated with the level of blood Phenylalanine, which in turn shows the severity of the enzyme defect (Pietro and Concolino, 2014).PKU diet and the new existing treatments, that need to be optimized, may be a complete and combined strategy possibly positively influencing the psychological, social, and neurocognitive life of
PKU patients. The restriction of dietary phenylalanine remains the mainstay of PKU management and usually begins immediately after confirmation of this condition in a newborn(Giovannini et al., 2012). Dietary restriction of phenylalanine combined with a protein substitute prevents intellectual disability in patients with phenylketonuria (PKU). Current protein substitutes are associated with low adherence owing to unpalatability and burdensome administration regimens. The prolonged-release protein substitute designed with an ethyl cellulose and arginate coating masking the bitter taste, smell and reducing the osmolality of free amino acids are suitable for children with PKU. Most subjects, mixed the test protein substitute with food or fruit juice, had reduced blood phenylalanine levels and improved phenylalanine/tyrosine ratio (MacDonald et al., 2020).

The casual results of this phenomena are severe mental retardation and emission of mold smell, reduced hair growth and skin hives, 
brightening of hair and eye color, reduced growth, small brain and head round and neurological symptoms of epilepsy, including repeated legs and hands movements. The patients who do not get remedied will probably develop behavioral problems such as hyper activity and anxiety (Enns et al., 2010). Phenylalanine is an amino-acid present in every protein containing food. PKU patients have a low tolerance for Phenylalanine and therefore, the dietary therapy of PKU patients requires high precision. This diet lacks any protein-containing food. These foods include dairy, red meat, fish, egg, cheese, walnut, cereals and bread dough, pasta, biscuits and cakes (NSPKU, 2010).Minimal requirements of phenylalanine $(9.1 \mathrm{mg} / \mathrm{kg} / \mathrm{d})$ are needed to meet the normal growth and development. Excess of phenylalanine (not required for protein anabolism) is mainly metabolized in the liver by PAH. In the United Kingdom, a system of protein exchanges is used, with approximately each $1 \mathrm{~g}$ of natural protein representing a phenylalanine load of $50 \mathrm{mg}$. Most children with PKU can tolerate less than $500 \mathrm{mg}$ of phenylalanine or $10 \mathrm{~g}$ of protein exchanges in 24h (Hendriksz and Walter, 2004; Pencharz et al.,2007).Amir and Ramezan(2017) showed that the analog kefir has a low level of phenylalanine $(30.40 \mathrm{mg} / 100 \mathrm{~g})$, and in this regard, it can be useful for patients with PKU.

Khandelwalet al.(2006) found that turmeric contains various chemical constituents such as atumerone, b-tumerone, zingiberine and curcumin. These are mainly digestive disorders. Osteoarthritis, atherosclerosis, cancer, intestinal worms, liver diseases and several bacterial infections are very effective in treating wounds and eye disorders. The oil of turmeric is also a very good mosquito repellent.Therefore, the target of this study was to produce different formulaof biscuits and flat bread low in protein and phenylalanine by using corn starch, potato flour andthickening agents (xanthan gum, Guar gum, carrageenan gum or mixture of Guar gum $\&$ carrageenan gum). The chemical composition, physical, texture and sensory properties of the biscuits and flat bread were determined.

\section{MATERIALS AND METHODS}

\subsection{Materials}

Cornstarch and potato flour were obtainedfrom the Egyptian and Italian Company for corn products, $10^{\text {th }}$ of Ramadan City, Egypt.Palm oil, sugar, baking powder, salt, vanilla andturmeric powder, were obtained from local market, Giza, Egypt. Xanthan gum, Guar gum, carrageenan gum, corn starch and monoglyceride were purchased from ElGomhoria Company for Drugs and Chemicals, Cairo, Egypt.

\subsection{Methods}

\subsubsection{Low protein Biscuits formula}

\subsubsection{Pre gelatinization corn starch preparation}

Two hundred grams of corn starch soaked in $200 \mathrm{ml}$ boiled water and mixed well.

\subsubsection{Biscuits preparation}

Biscuits preparation was carried according to the method of Schober et al. (2003) with some modifications. Thefore gelatinization cornstarch with different gumswere used in low protein biscuitsformula (control and its blends) (Table 1). The sugar, vanilla, monoglyceride and fat were creamed in a Hobart mixer for $15 \mathrm{~min}$. The cornstarch, potato flour, baking powder,

Table (1): Formula of Biscuits low in protein.

\begin{tabular}{|c|c|c|c|c|c|}
\hline \multirow{2}{*}{ Ingredients (g) } & \multicolumn{5}{|c|}{ Biscuits formula } \\
\cline { 2 - 6 } & Control & F1 & F2 & F3 & F4 \\
\hline Corn Starch & 700 & 700 & 700 & 700 & 700 \\
\hline Pre-gelatinized Corn starch & 200 & 200 & 200 & 200 & 200 \\
\hline Potato Flour & 100 & 100 & 100 & 100 & 100 \\
\hline Palm Oil & 300 & 300 & 300 & 300 & 300 \\
\hline Sugar & 375 & 375 & 375 & 375 & 375 \\
\hline Monoglyceride & 40 & 40 & 40 & 40 & 40 \\
\hline Xanthan gum & - & 8 & - & - & \\
\hline Guar gum & - & - & 8 & - & 4 \\
\hline Carrageenan gum & & & - & 8 & 4 \\
\hline Baking Powder & 14 & 14 & 14 & 14 & 14 \\
\hline Salt & 2 & 2 & 2 & 2 & 2 \\
\hline Vanilla & 0.8 & 0.8 & 0.8 & 0.8 & 0.8 \\
\hline Turmeric powder & 0 & 2 & 2 & 2 & 2 \\
\hline Water (ml) & 250 & 250 & 250 & 250 & 250 \\
\hline
\end{tabular}


turmeric powder and salt were added and mixed well for $5 \mathrm{~min}$ to obtain dough. The water was addedgradually to obtain smooth dough. The dough was sheeted to a thin ( $3 \mathrm{~mm}$ thickness) and cut to shape. The biscuits were baked in oven at $180^{\circ} \mathrm{C}$ for $15-18 \mathrm{~min}$ to reach a golden color. The biscuits were let to cool in room temperature and packing until testing.

\subsubsection{Flat bread making}

Flat bread blends were prepared as shown in Table (2). The pre-gelatinized cornstarch and potato flour with different gums, $2 \%$ baking powder, $5 \%$ palm oil, $2 \%$ turmeric and $2 \%$ salt were mixed well,then water added and knocked for $20 \mathrm{~min}$ and flattened to $2.5 \mathrm{~mm}$ thickness between two sheets of polyethylene. The bread loaves were baked at $350-400^{\circ} \mathrm{C}$ for $1-2 \mathrm{~min}$. Bread loaves were allowed to cool down at room temperature for $1 \mathrm{hr}$ before testing and scoring. freezer and texture measurement was determined for three days in terms of hardness $(\mathrm{N})$. The experiments were conducted under ambient condition saccording to the method described by Gomez et al.(2007).

\subsubsection{Organoleptic characteristics of low protein biscuits and flat bread.}

Organoleptic characteristics of biscuits and breadsamples were evaluated according to Hoojjat and Zabik (1984)with some modifications.Ten semi-trained paneliststested the biscuitsamples for its characteristics, e.g. generalappearance, color, texture, taste and odor. While, bread samples were evaluated forroundness, firmness, taste, odor, color and overall acceptability.

\subsubsection{Statistical analysis}

The Data were analyzed using CoStat, version 3.03 for personal computers accordingto

Table (2): Formula of flat bread low in protein.

\begin{tabular}{|l|c|c|c|c|c|}
\hline \multirow{2}{*}{ Ingredients(g) } & \multicolumn{5}{|c|}{ Bread formula } \\
\cline { 2 - 6 } & Control & B1 & B2 & B3 & B4 \\
\hline Corn starch & 600 & 600 & 600 & 600 & 600 \\
\hline Pre-gelatinized Corn starch & 200 & 200 & 200 & 200 & 200 \\
\hline Potato flour & 200 & 200 & 200 & 200 & 200 \\
\hline xanthan gum & -- & 10 & -- & -- & -- \\
\hline Guar gum & -- & -- & 10 & -- & 5.0 \\
\hline Carrageenan gum & -- & -- & -- & 10 & 5.0 \\
\hline Salt & 20 & 20 & 20 & 20 & 20 \\
\hline Palm oil & 50 & 50 & 50 & 50 & 50 \\
\hline Turmeric & -- & 20 & 20 & 20 & 20 \\
\hline Baking powder & 20 & 20 & 20 & 20 & 20 \\
\hline Water (ml) & 400 & 400 & 400 & 400 & 400 \\
\hline
\end{tabular}

\subsubsection{Physical Evaluation of low protein Biscuits}

Physical properties of biscuit samples, i.e., weight, volume, thickness, diameter, spread ratio, specific volume and bulk density were determined according to the methods described by AACC (2000).

\subsubsection{Proximate Chemical Composition}

Moisture, ash, crude protein, fat and crude fiber contents were determined according to the methods outlined in AOAC(2000). Total Carbohydrate content was calculated by difference.

\subsubsection{Texture Determination}

A texture analyzer (BROOKFIELD CT3 TEXTURE ANALYZER, the Operating Instructions Manual No. M08-372-C0113, and Stable Micro Systems, USA) was used to measure the texture profile of biscuits samples.The breadsamples were stored in deep
Ott (1988). The tests used were ANOVA test and descriptive statistics test. A treatment effect was assumed statistically significant at $\mathrm{P}<0.05$.

\section{RESULTS AND DISCUSSION \\ 3.1.Proximate chemical composition of raw materials and biscuit samples}

Proximate composition of raw materials is summarized in Table 3.Corn starch showed low protein content and high carbohydrates (0.1and $99.48 \%$ ), respectively. These results agree with those reported by Zahran et al.(2008) who stated that protein value of cornstarch was $0.10 \%$ and carbohydrate value was $99.48 \%$. While, potato flour contained $12 \%$ and $88.28 \%$ protein and carbohydrate, respectively. These results agree with those reported by Karuna et al. (1996). The results in Table (4) indicated thatthe tested samples F1and F2 showed very low protein contents $(0.39 \%)$. The results also indicated that all formulated biscuits were characterized by 


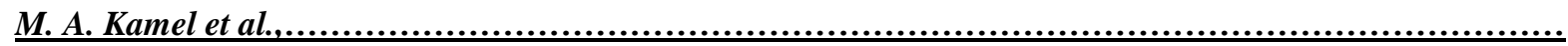

Table (3): Chemical Composition of Raw Materials (on dry Wight basis)

\begin{tabular}{|c|c|c|c|}
\hline Constitute (\%) & Potato flour & Corn Starch & Pre-gelatinized Corn Starch \\
\hline Moisture & $6.60 \pm 0.05$ & $4.01 \pm 0.02$ & $11.00 \pm 0.10$ \\
\hline Fat & $1.91 \pm 0.12$ & $0.16 \pm 0.15$ & $0.16 \pm 0.15$ \\
\hline Protein & $6.12 \pm 0.04$ & $0.10 \pm 0.03$ & $0.10 \pm 0.03$ \\
\hline Ash & $1.87 \pm 0.02$ & $0.25 \pm 0.05$ & $0.25 \pm 0.05$ \\
\hline Fiber & $1.82 \pm 0.15$ & $0.01 \pm 0.12$ & $0.01 \pm 0.12$ \\
\hline Carbohydrate $^{*}$ & $88.28 \pm 1.22$ & $99.48 \pm 1.19$ & $99.48 \pm 1.19$ \\
\hline
\end{tabular}

*Values are means of three replicates \pm SD.

*Total carbohydrate value was calculated by difference.

Table (4): Chemical composition of low protein biscuits (on dry Wight basis)

\begin{tabular}{|c|c|c|c|c|c|}
\hline Sample & Fat\% & Protein \% & Ash\% & Fiber\% & Total Carbohydrate\% $^{*}$ \\
\hline control controlcontrol & 15.76 & 0.40 & 0.15 & 0.47 & 83.22 \\
\hline F1 & 15.72 & 0.39 & 0.15 & 0.48 & 83.26 \\
\hline F2 & 15.72 & 0.39 & 0.14 & 0.48 & 83.27 \\
\hline F3 & 15.97 & 0.38 & 0.13 & 0.46 & 83.06 \\
\hline
\end{tabular}

*Total carbohydrate value was calculated by difference.

lower ashcontent between $(0.13-0.15 \%)$. These results agree with those reported by Yaseen and shouk(2011).Also, samples had considerable fat content (15.72- 16. 36\%). While, the fiber and total carbohydrate contents slightly affect with using different thickening agents of low protein biscuit samples.

\subsection{Physical Properties of Biscuits}

Physical properties of biscuits are important for both manufacturers and consumers. The quality of the examined biscuits is illustrated in Table (5). The data indicated that the weight in biscuits samples ranged between 24.52 and 27.60g. The samples F2 and F3 had the highest weight (27.35 and $27.60 \mathrm{~g}$ ) compared to control $(24.52 \mathrm{~g})$. These results may be attributed to the thickening agent more adoration of water compared with the control samples. The highest volume, thickness and diameter values of biscuits werefound in $\mathrm{F} 1(39.50 \mathrm{~cm}, 0.42 \mathrm{~cm}$ and $4.60 \mathrm{~cm})$ followed by $\mathrm{F} 2(37.50 \mathrm{~cm}, 0.37 \mathrm{~cm}$ and $4.25 \mathrm{~cm})$. The spread ratio and bulk density decreased with xanthan gum (F1) addition, compared to the control. Sarabhal et al. (2017)stated that hydrocolloids(Arabic gum and Carrageenan gum) were added to improve the quality of biscuits.

\subsection{Texture profile of low protein Biscuits}

Hardness was the maximum load, expressed in $\mathrm{Kg}$, applied to the samples during the first compression. Hardness was the force required to bite completely through the sample when placed between molars (Meulleneti et al., 1998). The hardness values of low protein biscuits are illustrated in Table (6). The control biscuits (without gums) had the higher hardness values $(63.00 \mathrm{~N})$ compared with biscuits samples. The hardness values ranged between $(43.20 \mathrm{~N})$ in F3 and $(41.89 \mathrm{~N})$ in $\mathrm{F} 1$ biscuits samples. The xanthan gum resulted in decrease in bread hardness on the day of baking and after $72 \mathrm{~h}$ of storage. At the same time, the bread reached best organoleptic scores(Mahmoud et al., 2013).

\subsection{Sensory Evaluation of Biscuit Samples}

Table (7) represents the values of sensory parameters for taste, texture, color, odor and general appearance of biscuit.Significant differenceswere observed between the samples for all sensory characteristics. Formula F1 scored the highest sensory than other formulas of texture and general appearance of biscuits samples. While, there was no differences in odor characteristic of all prepared formula biscuit. Browning of regular baked products depends to a large extent of the presence of protein. Low protein baked products had a tendency to brownless than those made from wheat flour (Yaseen et al.(2014). 
Table (5): Physical Properties of Low Protein Biscuit.

\begin{tabular}{|c|c|c|c|c|c|c|c|}
\hline Sample & $\begin{array}{c}\text { Weight } \\
(\mathbf{W}) \mathbf{g}\end{array}$ & $\begin{array}{c}\text { Volume } \\
(\mathbf{V}) \mathbf{c m}\end{array}$ & $\begin{array}{c}\text { Thickness } \\
(\mathbf{T}) \mathbf{c m}\end{array}$ & $\begin{array}{c}\text { Diameter } \\
(\mathbf{D}) \mathbf{c m}\end{array}$ & $\begin{array}{c}\text { Spread Ratio } \\
(\mathbf{D} / \mathbf{T})\end{array}$ & $\begin{array}{c}\text { Specific Volume } \\
(\mathbf{V} / \mathbf{W})\end{array}$ & $\begin{array}{c}\text { Bulk Density } \\
(\mathbf{W} / \mathbf{V})\end{array}$ \\
\hline Control & $24.52 \pm 0.035$ & $32.60 \pm 0.025$ & $0.33 \pm 0.055$ & $3.82 \pm 0.035$ & $11.58 \pm 0.055$ & $1.32 \pm 0.035$ & $0.75 \pm 0.002$ \\
\hline F1 & $25.02 \pm 0.121$ & $39.50 \pm 0.025$ & $0.42 \pm 0.035$ & $4.60 \pm 0.005$ & $10.95 \pm 0.169$ & $1.57 \pm 0.039$ & $0.63 \pm 0.007$ \\
\hline F2 & $27.35 \pm 0.148$ & $37.50 \pm 0.055$ & $0.37 \pm 0.035$ & $4.25 \pm 0.070$ & $11.49 \pm 0.177$ & $1.37 \pm 0.021$ & $0.72 \pm 0.014$ \\
\hline F3 & $27.60 \pm 0.154$ & $37.00 \pm 0.035$ & $0.36 \pm 0.007$ & $4.20 \pm 0.141$ & $11.67 \pm 0.141$ & $1.34 \pm 0.098$ & $0.77 \pm 0.042$ \\
\hline F4 & $26.14 \pm 0.424$ & $36.50 \pm 0.009$ & $0.36 \pm 0.035$ & $4.15 \pm 0.070$ & $11.53 \pm 0.070$ & $1.39 \pm 0.002$ & $0.71 \pm 0.001$ \\
\hline
\end{tabular}

*Values are means of three replicates \pm SD.

Table(6):Hardness of low protein biscuits.

\begin{tabular}{|c|c|}
\hline Sample & Hardness (N) \\
\hline Control & $63.00^{\mathrm{a}} \pm 0.32$ \\
\hline F1 & $41.89^{\mathrm{d}} \pm 6.23$ \\
\hline F2 & $42.36^{\mathrm{c}} \pm 1.58$ \\
\hline F3 & $43.20^{\mathrm{b}} \pm 4.65$ \\
\hline F4 & $42.54^{\mathrm{c}} \pm 1.32$ \\
\hline L.S.D & 0.348 \\
\hline
\end{tabular}

Means within the same column with the same letter(s) are not significantly different $(\mathrm{p}<0.05)$

Table (7): Sensory Evaluation of Biscuits.

\begin{tabular}{|c|c|c|c|c|c|}
\hline Sample & Taste (20) & Texture (20) & Color (20) & Odor (20) & $\begin{array}{c}\text { General } \\
\text { appearance }(20)\end{array}$ \\
\hline Control & $11.89^{\mathrm{e}} \pm 1.87$ & $8.98^{c} \pm 2.95$ & $18.39^{\mathrm{a}} \pm 2.00$ & $18.47^{\mathrm{a}} \pm 2.00$ & $9.25^{\mathrm{d}} \pm 2.07$ \\
\hline F1 & $16.67^{\mathrm{c}} \pm 3.04$ & $18.00^{\mathrm{a}} \pm 2.40$ & $18.20^{b} \pm 2.06$ & $18.28^{b} \pm 1.18$ & $19.22^{\mathrm{a}} \pm 0.54$ \\
\hline F2 & $16.33^{d} \pm 3.16$ & $17.11^{\mathrm{b}} \pm 1.96$ & $18.34^{\mathrm{a}} \pm 1.20$ & $18.26^{\mathrm{b}} \pm 2.15$ & $17.78^{\mathrm{c}} \pm 2.54$ \\
\hline F3 & $17.50^{\mathrm{b}} \pm 1.87$ & $17.22^{b} \pm 1.06$ & $18.51^{\mathrm{a}} \pm 2.00$ & $18.31^{\mathrm{b}} \pm 2.28$ & $18.00^{\mathrm{b}} \pm 2.07$ \\
\hline F4 & $17.77^{\mathrm{a}} \pm 1.96$ & $17.11^{\mathrm{b}} \pm 1.19$ & $18.37^{\mathrm{a}} \pm 2.24$ & $18.30^{b} \pm 2.55$ & $18.44^{b} \pm 1.07$ \\
\hline L.S.D & 0.256 & 0.4951 & 0.1732 & 0.1465 & 0.4781 \\
\hline
\end{tabular}

Means within the same column with the same letter(s) are not significantly different $(\mathrm{p}<0.05)$

\subsection{Chemical composition of produced flat bread}

Table (8) presents the moisture content of bread formulae. The moisture content was high in all bread formula (B1 to B4), while B1 and B2 had the highest moisture content between samples bread. While, the moisture content decreased gradually in different period storage. The moisture contents during freezing storage was the highest in B1 bread samples than other samples.Theincrease in the moisture content ofthe bread was considered to bedue to the constant dough consistency and the water bindingcapacity of the hydrocolloids, which decreased the degree of degradation during storage(Guarda et al. 2004).. Hydrocolloids are used in bakery products to control waterabsorption and, consequently, improve dough rheology and shelf life. The xanthancontaining formula(B1) had significantly higher water content in comparison with the guar gum (B2) (at similar concentrations) in fresh and stored bread.From data in Table (9), it could be seen that the protein content of flat bread under study ranged between 1.23 to $1.25 \%$. Thecontent of fat, ash, fiber and total carbohydrate of all treatments were slightly different compared with the control sample. 


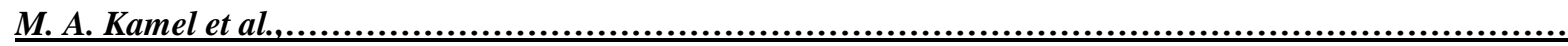

Table (8): Moisture content of flat bread at deferent time.

\begin{tabular}{|c|c|c|c|c|}
\hline \multirow{2}{*}{ Sample } & \multicolumn{4}{|c|}{ Moisture content (\%) } \\
\cline { 2 - 5 } & Fresh & First day & Second day & Third day \\
\hline Control & $46.84^{\mathrm{bc}}$ & $46.78^{\mathrm{b}}$ & $46.25^{\mathrm{b}}$ & $45.15^{\mathrm{c}}$ \\
\hline B1 & $50.26^{\mathrm{a}}$ & $49.29^{\mathrm{a}}$ & $48.95^{\mathrm{a}}$ & $48.53^{\mathrm{a}}$ \\
\hline B2 & $48.40^{\mathrm{b}}$ & $47.53^{\mathrm{b}}$ & $46.20^{\mathrm{b}}$ & $45.73^{\mathrm{b}}$ \\
\hline B3 & $47.58^{\mathrm{b}}$ & $47.35^{\mathrm{b}}$ & $46.21^{\mathrm{b}}$ & $45.63^{\mathrm{b}}$ \\
\hline B4 & $46.95^{\mathrm{bc}}$ & $46.87^{\mathrm{b}}$ & $45.14^{\mathrm{c}}$ & $45.62^{\mathrm{b}}$ \\
\hline L.S.D & 0.9874 & 0.8763 & 0.6541 & 0.4352 \\
\hline
\end{tabular}

Means within the same column with the same letter(s) are not significantly different $(p<0.05)$

Table (9): Chemical composition (\%) of produced flat bread (on dry Wight basis).

\begin{tabular}{|c|c|c|c|c|c|}
\hline Sample & Fat & Protein & Ash & Fiber & Total Carbohydrate $^{*}$ \\
\hline Control & 3.26 & 1.24 & 0.24 & 0.54 & 94.72 \\
\hline B1 & 3.22 & 1.25 & 0.25 & 0.48 & 94.80 \\
\hline B2 & 3.22 & 1.23 & 0.24 & 0.48 & 94.83 \\
\hline B3 & 3.27 & 1.23 & 0.23 & 0.46 & 94.81 \\
\hline B4 & 3.22 & 1.24 & 0.24 & 0.42 & 94.88 \\
\hline
\end{tabular}

*Total carbohydrate value was calculated by difference.

\subsection{Hardness of low protein flat bread}

The baked bread formulas were evaluated for hardness (Table 10). The bread formulas(B1) and (B2) hadthe highest hardness of both fresh and stored breads compared with control sample. Using xanthan (B1) and guar gum(B2) in bread formula had more effect on hardness compared with other treatments. This results may be due to the xanthan gum make electric bound with starch derivative and amylose this caused high texture.Gums, xanthan and xanthan-guar gum mixture were observed to be the most effective gums improving dough structure, while the best firmness value was obtained in breads containing xanthan and xanthan-guar (Demirkesen et al., 2010). diversty between roundness and firmness, and higher than the control. The overall acceptability of low protein bread samples with different hydrocolloids showed palatability than the control sample. It has been documented that gums usually improve the cohesion of starch granules, producing the required bread structure, mouth feeling and loaf volume, which are comparable in quality to those of the commonly accepted breads (Ozboy, 2002). Lazaridou et al. (2007) also added that, the addition of CMCgave high sensory characteristics score, high elasticity, as well as the elasticity of pectin and xanthan at $2 \%$ separately. Guarda et al.(2004)reported that hydrocolloids improve the sensory properties of bread. Freshness and

Table (10):Hardness (N) of low protein flat bread.

\begin{tabular}{|c|c|c|c|c|}
\hline \multirow{2}{*}{ Sample } & \multicolumn{4}{|c|}{ Hardness (N) } \\
\cline { 2 - 5 } Control & Fresh & First day & Second day & Third day \\
\hline B1 & $9.25 \pm 0.05$ & $9.42 \pm 0.07$ & $7.84 \pm 0.03$ & $6.92 \pm 0.09$ \\
\hline B2 & $16.12 \pm 0.09$ & $12.91 \pm 0.02$ & $11.79 \pm 0.05$ & $11.58 \pm 0.11$ \\
\hline B3 & $15.41 \pm 0.03$ & $11.63 \pm 0.05$ & $11.41 \pm 0.09$ & $10.40 \pm 0.05$ \\
\hline B4 & $12.45 \pm 0.06$ & $10.75 \pm 0.09$ & $10.41 \pm 0.06$ & $10.00 \pm 0.03$ \\
\hline
\end{tabular}

$*$ Values are means of three replicates $\pm \mathrm{SD}$

\subsection{Sensory Evaluation of flat bread}

Table (11) represents the mean values of sensory evaluation of bread for roundness, firmness, taste, odor, colorandoverall acceptability. The bread samples prepared withdifferent hydrocolloids showed slight moisture content of flat bread this may be due to the presence of high amount of starch and dilution of the protein in all formulas. Mahmoud et al. (2013) stated that bread with addition of xanthan gum has higher volume in comparison with pectin and guar. higher amount of xanthan 
Table (11): Sensory evaluation of low protein flat bread.

\begin{tabular}{|c|c|c|c|c|c|c|}
\hline Sample & Roundness & Firmness & Taste & Odor & Color & Overall acceptability \\
\hline Control & $2.50^{\mathrm{e}} \pm 0.89$ & $1.30^{\mathrm{d}} \pm 0.19$ & $15.20^{\mathrm{d}} \pm 0.61$ & $17.25^{\mathrm{ab}} \pm 0.41$ & $15.70^{\mathrm{a}} \pm 0.29$ & $1.4^{\mathrm{d}} \pm 0.75$ \\
\hline B1 & $7.40^{\mathrm{a}} \pm 1.14$ & $7.60^{\mathrm{a}} \pm 0.89$ & $16.20^{\mathrm{a}} \pm 2.05$ & $17.60^{\mathrm{a}} \pm 0.89$ & $15.60^{\mathrm{a}} \pm 1.82$ & $6.50^{\mathrm{a}} \pm 0.45^{\mathrm{a}}$ \\
\hline B2 & $7.20^{\mathrm{b}} \pm 1.30$ & $6.80^{\mathrm{b}} \pm 1.30$ & $15.60^{\mathrm{c}} \pm 2.61$ & $17.45^{\mathrm{a}} \pm 1.52$ & $15.70^{\mathrm{a}} \pm 1.92^{\mathrm{a}}$ & $6.00^{\mathrm{c}} \pm 0.50^{\mathrm{a}}$ \\
\hline B3 & $7.12^{\mathrm{c}} \pm 1.30$ & $6.50^{\mathrm{bc}} \pm 1.30$ & $16.00^{\mathrm{b}} \pm 2.74$ & $16.62^{\mathrm{c}} \pm 1.82$ & $15.65^{\mathrm{a}} \pm 3.78$ & $6.70^{\mathrm{a}} \pm 1.58^{\mathrm{d}}$ \\
\hline B4 & $7.00^{\mathrm{d}} \pm 1.87$ & $6.60^{\mathrm{b}} \pm 2.07$ & $15.00^{\mathrm{e}} \pm 2.74$ & $16.62^{\mathrm{c}} \pm 1.82$ & $15.11^{\mathrm{ab}} \pm 3.78$ & $6.30^{\mathrm{b}} \pm 1.58$ \\
\hline L.S.D & 0.0547 & 0.2451 & 0.1453 & 0.3456 & 0.5425 & 0.1425 \\
\hline
\end{tabular}

Means within the same column with the same letter(s) are not significantly different $(p<0.05)$

gum resulted in decrease in bread hardness on the day of baking and after $72 \mathrm{~h}$ of storage. At the sametime, the bread reached best organoleptic scores.

\section{REFERENCES}

AACC (2000). American Association of Cereal Chemists. Approved Method of the AACC, $10^{\text {th }}$ Ed. American Association of Cereal Chemists, St. Paul, Minnesota, USA,pp: 2570.

Amir Y. and RamezanY.(2017). Analog kefir production with a low phenylalanine for Phenylketonuria. J. Pharmaceut. and Health Sci., 5 (2): 111-120.

A.O.A.C. (2000).Official Methods of Analysis of the Association of Official Analytical Chemists International $17^{\text {th }}$ ed. Published by the Association of Official Analytical Chemists International ,Suite 400, 2200 Wilson Boulevard, Arlington, Virginia 22201-3301, USA.

Blau N., Van Spronsen F.J. and Levy H.L. (2010). Phenylketonuria. The Lancet, 376 (9750): 1417-1427.

Demirkesen T., Behic M., Gulum S. and Serpil S. (2010). Rheological properties of gluten-free bread formulation. J. Food Eng., 96: 295-303

Enns G.M., Koch R., Brumm V., Blakely E., Suter R. andJurecki E. (2010). Suboptimal outcomes in patients with PKU treated early with diet alone: Revisiting the evidence. Mol. Genet. and Metabol.,101(2):99-109.

Giovannini M., Verduci E., Salvatici E., Paci S. and Riva E. (2012). Phenylketonuria: nutritional advances and challenges Nutri.\& Metabol., 9 (7):1-7.

Gomez M., Ronda F., Coballera A.P., blanco A.C. and Rosell M.C. (2007). Functionality of different hydrocolloids on the quality and shelf life of yellow layer cakes. Food Hydrocoll., 21(2): 167-173.

Guarda A., Rosell C.M., Benedito C. and Galotto M.J. (2004).Different hydrocolloids as bread improvers and ant stalling agents. Food Hydrocoll., 18: 241-247.

Hendriksz C.J. and Walter J.H. (2004). Update on phenylketonuria. Curr. Ped., 14400406.

Hoojjat P. and Zabik M.E. (1984). Sugar-snap cookies prepared with wheat-navy bean sesame seed flour blends. Cereal Chem., 61: 41-44.

Karuna D. Govinden K. N. and Kulkarni D. (1996). Production and use of raw potato flour in Mauritian traditional foods. Food and Nutr. Bull., 17 (2):162-168.

Khandelwal L. K.,Sapakal M. R., Sakarkar D.M. and Pardesi M.D.(2006).Turmeric a miracle of Ayurveda,. Plant Arch., 6 (2):429-432.

Lazaridou A., Duta D., Papa Georgiou M., Belk N. andBiliaderis C.G. (2007).Effects of hydrocolloids on dough rheology and bread quality parameters in gluten-free formulations. J. Food Eng., 79: 10331047.

MacDonald A., Ashmore C., Daly A., Pinto A. and Evans S. (2020). An Observational Study Evaluating the Introduction of a Prolonged-Release Protein Substitute to the Dietary Management of Children with Phenylketonuria, Nutrients, 12(9): 2686.

Mahmoud R.M.,Yousif E.I., GadallahM.G.E. and Alawneh A.R. (2013).Formulations and quality characterization of gluten-free Egyptian balady flat bread, Ann. Agric.Sci., 58 (1): 19-26

Meulleneti J. F., Lyon B.G., Carpenter J.A. and Lyon C.E. (1998).Relationship between sensory and instrumental texture profile 
attributes. J. Sens. Stud., 13(1): 77-93.

NSPKU (2010). Phenylketonuria Information for GPs about Diet and PKU.The National Society for Phenylketonuria (United Kingdom) Ltd., 1 of 3.

Ott L. (1988). An introduction to statistical methods and data analysis. $3^{r d}$ ed. PWSKent, Boston, MA, USA.

OzboyO. (2002).Development of corn starchgum bread for phenylketonuria patient.Food-Nahrung, 46(2):87-91.

Pencharz B., Hsu W. and Ronald O. (2007). Aromatic amino acid requirements in healthy human subjects. J. Nutr., 137: $1576 \mathrm{~S}-1578 \mathrm{~S}$.

Pietro S. and Concolino D. (2014). New Strategies for the treatment of Phenylketonuria (PKU). Metabolites, 4 (4): 1007-1017.

Sarabhal S., Sudha M. L. and Prabhasankar P. (2017). Rheological characterization and biscuit making potential of gluten free flours. Food Measure, (11):1449-1461.

Schober T.J., O'Brien C.M., McCarthy D.,DarneddeA. andArendt E.K. (2003). Influence of gluten-free flour mixes andfat powders on the quality of gluten-free biscuits. Eur. Food Res.Tech., 216:369376.

Yaseen A.A. and Shouk A. A. (2011). Low Phenylalanine Egyptian Shamy Bread. Pol. J. Food Nutr. Sci., 61(4): 257-262.

Yaseen A.A., Shouk A.A. and Bareh G.F. (2014). Production of functional biscuits for phenylketonuria patients. World Appl. Sci. J., 31(5):692-697.

Zahran A.H.G., Sahar S. El-Goheryand Dalia M. El-Shak (2008). Production of biscuits low phenylalanine for people suffer from phenylketonuria. Egypt. J. Nutr., XXIII (4): 29-52.

$$
\begin{aligned}
& \text { إعداد وتقييم بعض منتجات المخابز المنخفضة جدا في البروتين لمرضى الفينيل كيتونوريا } \\
& \text { مسعود عبد العظيم كامل- جمال عبد الحميد زهران - حياة محمد نصرعفيفى } \\
& \text { قسم بحوث الخبز و العجائن الغذائيةـ معهد بحوث تكنولوجيا الأغذيةــ مركز البحوث الزر اعية }
\end{aligned}
$$

تهدف هذه الدراسة إلى استخدم دقيق البطاطس ونشا الذرة لإعداد بسكويت وخبز مسطح لمرضى الفينيل كيتونوريا.

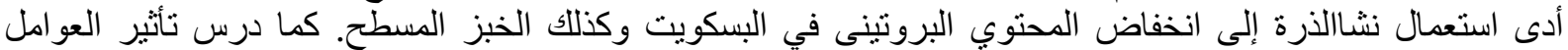

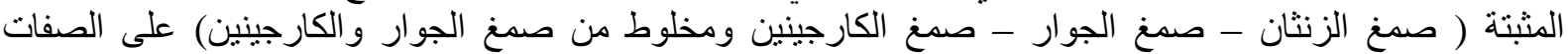

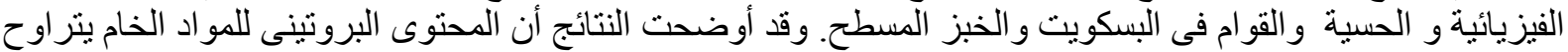

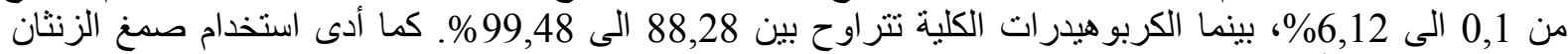

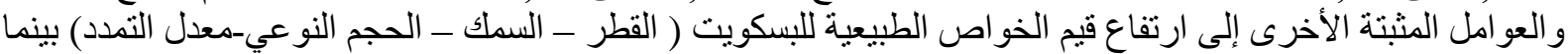

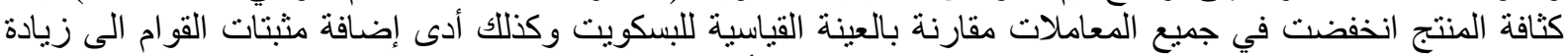

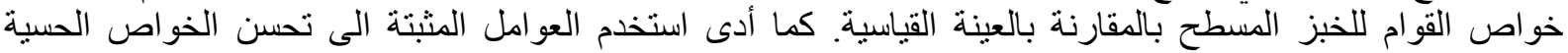

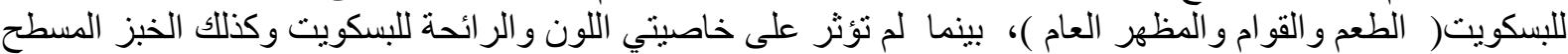

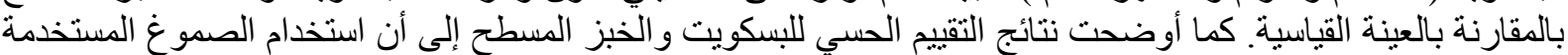

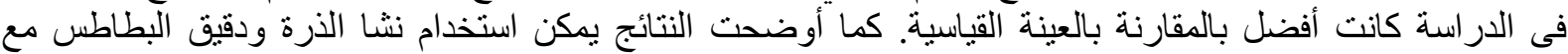

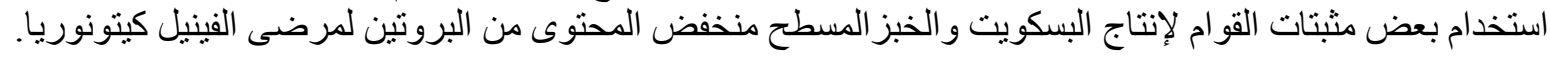

المجلة العلمية لكلية الزراعة - جامعة القاهرة- المجلا (71) العدد الرابع اكتوبر (2020):286-296. 